\title{
EL CONSERVADURISMO EN LA POESÍA ÁRABE
}

\author{
ABDALLAH HAMMADI
}

El insigne maestro D. Emilio García Gómez, según mi criterio es un creador insuperable de temas de debate (o, mejor dicho, de temas dignos de ser abordados con rigor y firmeza...). Hojeando su estudio acerca de Ibn Zamrak se ve que su criterio acerca de esta época carece de elementos que justifiquen su visión global y gracias a su genuina intuición acierta en la mayor parte, como en el caso de este párrafo suyo, en el que dice: "Mientras las letras occidentales padecen con frecuente periodicidad terremotos estéticos que alteran por completo su fisonomía, la poesía árabe, desde el Islam, sufre apenas leves sacudidas sísmicas, ligeros desplazamientos espirituales que no llegan a quebrar el armazón de una técnica intangible. Mucha mayor libertad tuvo en tiempos anteislámicos para el desarrollo de particularidades indivisibles..."1.

Mi deseo es encontrar la respuesta a este planteamiento por parte del gran profesor, pero no ha sido más que plantear una serie de preguntas sin respuestas. Quizás esta respuesta, a mi modo de ver, pudiera deberse a muchos elementos coherentes entre sí y opuestos, pues hasta la mismísima época a la que atribuye García Gómez ciertas creaciones a nivel individual, se caracteriza por el fenómeno que predomina en el panorama conservador de toda la poesía árabe, de tal modo que no se puede decir que la aparición del Islam marcara un hito comprometido ni tampoco existió esa relativa libertad que permitió destacar individualidades.

${ }^{1}$ Emilio García Gómez, Ibn Zamrak. El poeta de la Alhambra, Granada, Patronato de la Alhambra, 1975 p. 76. 
La poesía ŷabilī se caracteriza por su autenticidad, su identidad propia y no por sus individualidades creativas, porque en su lírica trascendental cayó en tópicos que sólo basta citar (al-At-

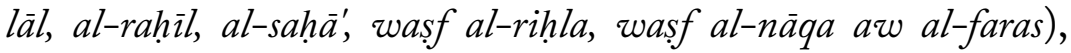
luego lo que se llama al-Istitrād, que es dejar el tema principal y describir temas que luego los críticos con derroche de esfuerzo intelectual intentan demostrar que existe una cierta unidad entre el tema principal y el al-Istitrād, y es una "unidad artística" (wihda fanniyya) aunque esto a mi modo de ver es pura elucubración. El poeta ŷabilī sentía en su fisonomía el elemento de la libertad y eso se debe a su contorno ambiental, pero por otro lado se encontraba ligado a una gran familia que es su tribu, donde la 'așabiyya (lazos de sangre), según Ibn Jaldún era el elemento fundamental; entonces, sin llegar más allá, cayó en el tópico, y son de sobra conocida las quejas de Imri'-1-Qays, Zuhayr y 'Antara ${ }^{2}$ por lo estrecho que se encontraba el campo artístico de la poesía.

Algunos enfocan el asunto desde otro punto de vista y creen que al Islam se debe la pérdida de varios géneros que debieron existir en la Ŷabiliyya. ¿Cómo nos ha podido llegar el género llamado saŷ $a l-k u b h a ̄ n$, prosa rimada de los paganos, por su dificultad de transmisión, comparándola con la poesía que es algo fácil para la memoria?

Puedo deducir de todo esto que el poeta no tenía más remedio que seguir las corrientes de su tiempo, reflejadas en los moldes concretos que se imponen por parte del ambiente artístico, o quedar marginado. Así se representan los moldes perfecto de la poesía $\hat{y} a b i l i ̄$ en las múallaqāt, ejemplo supremo de la creación poética y modelo de cómo se debe componer el poema para impresionar y ganar la emoción del oyente. En definitiva, la época ŷabilī no estuvo libre del fenómeno "conservador" que

${ }^{2}$ Šawqī Dị̂, Al-fann wa wadābibu-hu fì-al-sìr, El Cairo, 1943, pp. 5-6. 
va a aumentar en el futuro y seguir vivo en la tradición poética árabe hasta nuestros días. Llegó el Islam y la acusación dirigida al Profeta fue que sus palabras eran poesía. Azora no 21 , aleya 5: "No — responden los infieles_ ¡son sueños turbios! ¡Él lo forjó! ¡Él es un poeta! ¡Tráenos una aleya similar a las que se mandaron a los primeros enviados!". Y tuvo que defenderse de los ataques y dar el criterio del Islam en lo que concierne a cómo debe ser un poeta, azora no 26 aleyas 2-28: "los que creen, hacen obras pías, invocan en frecuencia a Dios”.

Pese a la postura del Islam respecto a la poesía y los poetas, el Profeta no tuvo más remedio que utilizar esta arma y luchar contra sus enemigos. Sus poetas comprometidos son muy conocidos, basta recordar el nombre de Hasān b. Tāâbit, que entró en la historia de la poesía con el apodo de "poeta del Profeta" y otros como Ka'b b. Zuhayr, etc. La poesía en la época islámica, y me refiero a la heredada de los $\hat{y} a \bar{b}$ ilīes, ha servido como manantial para los poetas, tanto para adquirir riqueza léxica, como conocimientos históricos y genealógicos que sirvieron para defender sus honradas raíces frente a una nueva invasión ideológica... Entonces para explicar o entender el Corán hay que conocer la poesía $\hat{y} \bar{a} h i l \bar{\imath}$, para buscar la perfección gramatical hay que ver cómo pronunciaban los ŷāhilīes, para componer buenas alabanzas hay que acudir a Zuhayr o a al-Nābiga... También la sátiras resucitaron con las nuevas generaciones islamizadas y arabizadas, porque ahí yace la perfección léxica: estos moldes arraigan en las gentes y emigran con ellas a los nuevos territorios conquistados por los nietos de los ŷähilīes como parte sentimental y patrimonio heredados de antaño. Con este espíritu conservador se enfrentaron a las nuevas sociedades y los cimientos de la poesía arcaica se mantuvieron firmes, burlándose de las quejas de Abū Nuwās, de Baššār, los intentos de Abū Tammām (véase al-Muwāzana). La emigración hacia nuevos territorios y sociedades sirvió como elemento fundamental para la 
conservación del pasado heredado, los anhelos de 'Abd al-Rạ̣mān I dialogando con la palmera son prueba de la añoranza de un pasado lejano que caracteriza al periodo omeya y aquel que vive en Damasco dirige su pensamiento hacia el Naŷd o Tihāma.

Por eso al abordar este tema, tanto Blanchére como García Gómez no dieron importancia a este fenómeno, que más o menos ha tocado el insigne Vicente Cantarino en su estudio re-

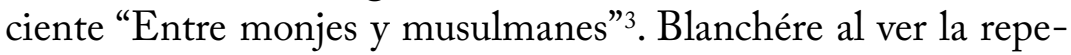
tición continua que caracteriza a la poesía árabe en lo tocante a metáforas y lenguaje, lo calificó como "negligencia o falta de esfuerzo del poeta", y ese criterio lo dedujo hablando de Ibn $\mathrm{Za}-$ mrak, García Gómez veía en la repetición de ciertos topónimos una idea arraigada en el subconsciente. Todo esto, a mi modo de ver, se debe a lo que hemos citado y a algo más: el poeta árabe por su rápida emigración, se encontró lejos de su tierra y llevó su pasado como recuerdo o sueño vago y cada vez que encuentra este pasado representado en un poema, una historia o un nombre de lugar, se aferra a él desesperadamente. A esto alude Ibn Bassām (m. 1149) en su Dajīra, de quejarse de la gente andalusí: "Los de este país que escribieron literatura no se propusieron otra cosa que seguir e imitar a los escritores de Oriente... de tal modo que, si en aquellas regiones grazna un cuervo o en la más lejana comarca de Siria o Iraq zumba una mosca, doblan su rodilla ante esto, cual si fuera ídolo y leen estas cosas como si se tratase de un libro notable". Los gritos de Ibn Bassām fueron en vano, tal como los de Ibn Hānī al que molestaba el aprecio de la gente de su tierra andalusí por alMutanabbī, estando él a la misma altura. Todas estas quejas fueron sin eco y lo mismo se decía en Oriente, tanto en la época omeya como en la 'abbasí, contra las continuas alusiones al de-

${ }^{3}$ Vicente Cantarino, Entre monjes y musulmanes: El conflicto que fue España, Madrid, Alhambra, 1978, pp. 18-76. 
sierto de Naŷd y a la península arábiga y su historia preislámica. Es un clamor de exiliado, son anhelos de expatriado que no pudieron borrar ni el espacio ni el tiempo. A este elemento se debe el fenómeno conservador y la carencia de terremotos estéticos. Otras circunstancias también lo respaldaron; al pensar los árabes en glorificar su lengua y componer reglas gramaticales, no tuvieron más remedio que volver otra vez al desierto y tener como fuente de inspiración a los beduinos de pura cepa. Lo mismo ocurrió con el Corán para comentarlo y explicar sus palabras, sin olvidar que todavía no existía la escritura y los hijos de los beduinos junto a las espadas y debajo de las corazas llevaban la única herencia cultural que poseían, esto es, las casidas para ufanarse ante las civilizaciones persa y bizantina. Esto es lo que llevaban junto a la nueva ideología espiritual; gracias a lo cual nació la transmisión oral (الرواية) , fenómeno que vino como vínculo para forzar el espíritu conservador y exigía una cadena que permitiese vivir la tradición continuamente sin darse uno cuenta. A consecuencia de eso al-Intihăl (el plagio) ${ }^{5}$; muchos trasmisores por fuerza de la influencia, compusieron en varias ocasiones con el mismo estilo y espíritu obras que atribuyeron a poetas $\hat{y} \bar{a} h i l i \overline{e s}$, todo para obtener el prestigio de transmisor y conservador de la herencia. La crítica, tanto clásica, encabezada por Ibn Sallam al-Ŷumahī en su Tabaqāt como moderna, con

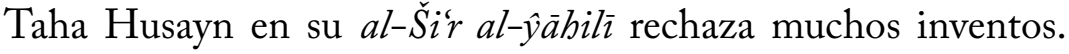
Baste con citar a Hamad 'Aŷrad y Jalaf al-Ahamr al que se atribuye la famosa lāmiyya (J) del poeta bandolero al-Šanfarà. Junto a este fenómeno nació la rigurosa crítica que exige según la línea tradicional y crea nuevas imágenes. Así tenemos otra ca-

${ }^{4} \mathrm{Ni}$ 'mat Rahīm al-'Azawī, Al-Naqd al-luqawī 'ind al-'arab hatt' nihāyat al-qarn al-sābi'al-bî̀rī, Bagdad, Wizarat al-I'lām, pp. 35-52.

5 Julio Samsó, "La cultura árabe preislámica", en Revista Histórica 16, 1979, año IV, núm. 38, pp. 73-74. 
dena de transmisiones de versos que nos indica, por ejemplo, que tal verso de al-Mutanabbī está inspirado en Abū Tammām, éste en Ŷarīr, éste en al-Nābiga, etc. Nació lo que se llama ( "التوليد / (recreación) y así quedó la poesía árabe en un círculo vicioso, sin salir de él y sin romperlo, por puro afán de permanecer en contacto con el lejano pasado, y surgió la nueva forma crítica que defiende el porqué los poetas caigan en el tópico o repitan imágenes y metáforas creadas por poetas anteriores. Lo mejor que se ha escrito hasta ahora acerca de esto desde mi punto de vista es la epístola de lbn Rašiq al-Qayrawānī titulada Qurādat al-dahab ${ }^{6}$ que compuso tras haber sido acusado de haber "robado" unas metáforas de dos versos del poeta al-Nahšalī y demostró en este magistral ensayo cómo pasan las imágenes poéticas de un poeta a otro.

Otro elemento fundamental para el fenómeno conservador y que evitó las tormentas estéticas fue la tradición del aprendizaje de memoria de miles de versos, que en primer lugar sirvió de transmisión de la cultura y en los tiempos anteriores, casi desde la época 'abbasí tomó otro concepto. Así vemos que Abū Nuwās, no sabiendo cómo llegar a ser buen poeta, fue aconsejado por su maestro Wāliba para que se retirara al desierto y se comunicara directamente con los beduinos, conservadores del más puro árabe, y aprendiera de memoria miles de versos. Abū Nuwās se regocijó con esta idea, la cumplió y, sin darse cuenta, regresó ya con los moldes que anteriormente hemos explicado, cargado de todo lo tradicional; como no le faltaba don para la poesía, expresó sus sentimientos según los moldes grabados en su mente y ya no se pudo librar del sonido de las rimas ni pudo traspasar las fronteras de los metros tradicionales, pese a sus in-

${ }^{6}$ Ibn Rašīq al-Qayrawānī, Qurādat al-ḍahab, El Cairo, Maktabat alJānŷī, 1926, pp. 10-59. 
tentos cuando consiguió su madurez creativa. Abū Nuwās, según mi criterio, es uno más que se añade al conocido círculo monótono, y así anduvieron todos los que buscaron la vía de la poesía, compitiendo en el aprendizaje de los miles de versos. Abū Tammām se enorgullece y se siente insuperable al mencionar que sabía de memoria 14.000 arŷuzza (poemas rimados por el exterior y el interior) tal como conocemos por su famosa antología titulada al-Hamasa, al igual que su discípulo al-Buhturī. Lo mismo se dice del genio de la poesía árabe, al-Mutanabbī, que antes de alcanzar la fama tuvo que pasar por la escuela beduina. Ibn Jaldún repite este fenómeno con claridad en sus prolegómenos (Muqaddima) aconsejando a los jóvenes aprender de memoria miles de versos para llegar a ser poetas y añade que la mente humana se expresará según el contenido que la llena, si se aprende buena poesía, se escribirá buena poesía y si se aprenden cosas malas, se expresará uno de manera correspondiente ${ }^{7}$, como dice el refrán: "cada recipiente rezuma de lo que tiene", aplicó la experiencia a él mismo y se asombró del enorme número de poesías que llegó a aprender, pero como él nació para otros menesteres no pudo tener éxito en la poesía, expresando sus sentimientos con poemas de bajo nivel estético ${ }^{8}$. Al poeta por tanto sólo le quedaba una salida, o bien recrear (ولد (و) las imágenes antiguas en nuevas creaciones o seguir en la línea que García Gómez definió a Ibn Zamrak: "su literatura es por lo general arcaizante, glosas de glosas, comentarios, erudición, reiteración en poesía y prosa de arte, de tópicos y clisés precedentes. Incluso en el terreno de la historia de las instituciones y de la doctrina política se han limitado demasiado a menudo, dice el prof. G. S. Colín, a recomponer los modelos clásicos que re-

${ }^{7}$ Ibn Jaldún, Muqaddima, edición de A. M. Katemir, Beirut, 1970, tomo III, pp. 336 y 346-351.

\section{${ }^{8}$ Ibidem.}


presentaban los diversos organismos del Estado como cabrían de ser teóricamente, en vez de describirlas tal como los veían

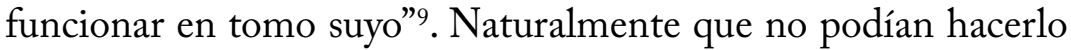
por el puro afán de traer a la línea conservadora nuevas fórmulas metafóricas que quizá den al poeta una cátedra junto a los inmortales. Para apoyar más nuestro criterio brindo estas palabras de García Gómez con las que estoy totalmente de acuerdo: "La obra de Ibn Zamrak - y este criterio se puede aplicar a cualquier poeta - es una especie de museo donde están expuestos y catalogados, aunque un poco empalidecidos, todos los temas de la lírica anterior; un vasto cementerio donde en tumbas perfectamente alineadas yacen todos los tópicos de la poesía arábigo-andaluza" ${ }^{10}$.

Todavía falta algo importante, aunque ya lo nombré anteriormente, con los fenómenos de la métrica y de la rima. Para conseguir ser maestro de estos moldes hay, antes de empezar a escribir poesía, que adquirir musicalidad y una rima sonora que necesita una riqueza léxica infinita. Para adquirir todo esto se acude a la memoria, por eso fueron famosos los grandes memoristas, por ejemplo en la Granada nazarí Ibn Ŷuzay al-Kalbī era temido por su vasto dominio memorístico de la poesía clásica, al igual que Ibn Jamīs de Tremecén y otros.

Se deduce de todo lo citado que el poeta se encuentra otra vez atado a lo tradicional: si quiere alabar, saltan a su memoria miles de poemas de este género, si quiere escoger una rima concreta se encuentra cogido por los moldes o modelos anteriores y cada vez más siente el poeta la estrechez del espacio creativo y a la fuerza cae en el tópico. Cuando alguna vez logra librarse es si el tema, la rima o el metro no son del mismo género del poema anterior aunque saltarán a la vista del crítico modelos y frases

\footnotetext{
${ }^{9}$ Emilio García Gómez, ob. cit., p. 12.

${ }^{10}$ Ibid., p. 82.
} 
hechas e imágenes adquiridas que dejan sentir la caída del poeta en el bando conservador y tópico. Los ejemplos de esto son innumerables; basta repasar cualquier poema panegírico o satírico para sentar entre líneas el rastro de las grandes figuras que fueran símbolo que caracteriza este campo: en las sátiras sobresale al-Ḥutay'a, Ŷarīr y su compañero al-Farazdaq, Buššār, etc., y en el panegírico y la descripción de batallas no puede olvidarse el fervor de al-Mutanabbī, y en la poesía de autoalabanza jamás queda lejana la figura de Abū Firās, sino que se siente entre los de al-Mu'tamid, rey de Sevilla. Si busca el poeta el género floral, no tiene más remedio que acudir a al-Sanawbarī, y si aspira al amor espiritual no deja de repasar la poesía 'Uḍrī. Por eso la poesía árabe se caracteriza por su temperamento conservador y aburrido, pese a haber sufrido algunas convulsiones producidas por las Muwaššahat y los zéjeles, que por su carácter extraño al común de la poesía árabe fueron rápidamente desechados y no llegaron más allá del siglo XIV. Ibn al-Jațịb nos informa: "Las Muwaššahat fueron un invento propio de los andalusíes que hoy día han desaparecido"11. Es decir por su ilegitimidad fue rechazada la Muwaššaha, pues no cumplía con todo lo que hemos explicado, además la larga trayectoria de la poesía árabe a mi modo de ver se queda sabiamente difundida por la visión inteligente de Don Emilio García Gómez que siempre acierta cuando dice: "Entre nosotros la perspectiva general histórica la poseen algunos artistas de excepción, y, por vía profesional, los historiadores y los eruditos, mientras los artistas normales representan su papel ante el telón corto de su propia y limitada crítica. Entre los árabes, en cambio, no hay telones cortos, foros ni forillos: todos los artistas representan en un escenario nudo, cada día más amplio, y donde, por tanto, cada día se empeque-

${ }^{11}$ Ibn al-Jaṭīb, Ihāta fì ajbār Garnāṭa, edición de Muḥammad 'Abd 'Allāh 'Inān, El Cairo, 1978, vol, IV, p. 525. 
ñecen más las figuras. Nosotros medimos cada momento estético por su propio patrón, mientras los árabes lo mesuran por un patrón eterno" 12 .

12 Emilio García Gómez, "Un eclipse de la poesía en Sevilla", en $A l-$ Andalus, 1945, vol. X, p. 308. 